\title{
Dilatação cística do úraco e uroperitônio em touros: relato de cinco casos
}

\author{
[Cystic dilatation of the urachus and uroperitoneum in bulls: report of five cases] \\ L.C. Marques ${ }^{1}$, J.A. Marques ${ }^{1}$, I.C.S. Marques $^{2}$, M.C.A. Teixeira ${ }^{2}$ \\ ${ }^{1}$ Faculdade de Ciências Agrárias e Veterinárias - UNESP \\ Via de Acesso Prof. Paulo Donato Castellane, s/n \\ 14870-000 - Jaboticabal, SP \\ ${ }^{2}$ Aluna de pós-graduação - FCAV-UNESP - Jaboticabal, SP
}

\begin{abstract}
RESUMO
Descrevem-se os aspectos clínicos da dilatação cística do úraco e uroperitônio em cinco touros. Os animais apresentaram, em datas distintas, distensão abdominal e diminuição da ingestão de alimentos e água, até culminar com inapetência, cerca de duas semanas após o aparecimento dos primeiros sintomas. Ocorreu distensão abdominal bilateral progressiva, que, no início do processo, era discreta e restrita ao quadrante inferior do abdômen; com cerca de duas semanas de evolução, o abdômen assumiu forma arredondada semelhante à pera. Observou-se bruxismo, atonia ruminal e desidratação. A abdominocentese revelou a presença de líquido amarelado com concentração de ureia superior a $200 \mathrm{mg} / \mathrm{dL}$. A concentração de ureia no soro sanguíneo variou de 220 a $280 \mathrm{mg} / \mathrm{dL}$ e a creatinina de 65 a $82 \mathrm{mg} / \mathrm{dL}$. A ligadura do divertículo do úraco próximo ao vértex da bexiga foi eficaz nos quatro touros operados.
\end{abstract}

Palavras-chave: bovino, úraco, dilatação cística, uroperitônio

\begin{abstract}
The clinical findings and outcomes in five bulls with a perforation or rupture of the urachal diverticulum are described. All the bulls had a dilated round or pear-shaped abdomen, bruxism, ruminal atony, and dehidration. In all the bulls, abdominocentesis yielded a stream fluid and the serum concentrations of urea and creatinine were 220 to $280 \mathrm{mg} / \mathrm{dL}$ and 65 to $82 \mathrm{mg} / \mathrm{dL}$, respectively. Peritoneal fluid concentration of urea was higher than $200 \mathrm{mg} / \mathrm{dL}$. In fours bulls, urachal diverticulums were closed next to the cranial pole of the bladders. After the surgery, the recovery was effective.
\end{abstract}

Keywords: cattle, urachus, cystic dilatation, uroperitoneum

\section{INTRODUÇÃO}

No feto as estruturas umbilicais intra-abdominais consistem de uma veia, duas artérias e o úraco. Essas estruturas atravessam a cavidade abdominal para o exterior, através de um anel epitelial localizado na musculatura. $\mathrm{Na}$ porção extra-abdominal, existem duas veias, que, ao penetrarem na cavidade abdominal, se unem, dirigindo-se cranialmente ao fígado. Em sentido caudal, as artérias dirigem-se à artéria hipogástrica, e o úraco à bexiga. O úraco é uma

Recebido em 8 de março de 2010 Aceito em 20 de dezembro de 2010

E-mail: lmarques@fcav.unesp.br estrutura tubular que liga a bexiga ao alantoide durante o desenvolvimento fetal.

Em partos normais, o cordão umbilical exterioriza-se aproximadamente $10 \mathrm{~cm}$ fora da parede abdominal, e não existe, nos bovinos, um ponto extra-abdominal de ruptura do cordão, o que faz variar o tamanho do umbigo que fica exposto. Dentre as transformações anatomorfisiológicas que ocorrem a partir da ruptura do cordão umbilical, destaca-se a excreção urinária que era feita pelo úraco e passa a ser realizada pela uretra. Assim, o úraco, após o nascimento, se fecha e se transforma no 
ligamento médio da bexiga (Noden e De Lahunta, 1985).

Quando o úraco não se fecha após o nascimento, o lúmen permanece aberto, deixando uma abertura anormal entre a bexiga e o umbigo, levando ao gotejamento de urina, com riscos de infecções. As causas não estão bem definidas, mas parece não ter correlação com anomalias congênitas ou hereditárias. Desempenha papel importante no processo o desprendimento prematuro do cordão umbilical, agravado pelas lambidas e puxadas realizadas pela vaca. É um achado frequente e tem importância clínica na presença de infecções, neoplasias ou dilatação cística.

Assim, a única malformação da bexiga com importância em animais é a falha no fechamento do úraco. Ocasionalmente, a obliteração é parcial, o endotélio do úraco permanece intacto e desenvolve cisto em algum ponto entre a bexiga e o umbigo. Os divertículos da bexiga podem ser secundários à obstrução parcial do fluxo urinário ou da pressão normal de contrações em área anatomicamente fraca. Esta anomalia usualmente ocorre no vértex da bexiga onde há descontinuidade da musculatura, quando o fechamento do úraco é incompleto. Estase urinária, desenvolvendo persistente inflamação e formação de cálculos, pode ocorrer no divertículo (Jubb e Kennedy, 1970). A ruptura do úraco ocorre frequentemente em animais jovens e raramente em adultos (Baxter et al., 1992; Braun et al., 2006). O objetivo deste trabalho foi descrever divertículos do úraco perfurados em cinco touros.

\section{CASUÍSTICA}

Cinco touros, com idades entre cinco e sete anos, dois da raça Nelore, dois da Gir e um da Red Angus, apresentaram, em datas distintas, distensão abdominal e progressiva diminuição da ingestão de alimentos e água, até culminar com inapetência cerca de duas semanas após o aparecimento dos primeiros sintomas. A distensão abdominal bilateral, que no início do processo era discreta, foi progressiva e restrita ao quadrante inferior do abdômen; com cerca de duas semanas de evolução, o abdômen assumia aspecto pendulado (Fig. 1 e 2). Ainda, observouse bruxismo, com produção de saliva espessa e espumosa. Desenvolveu-se desidratação progressiva, a despeito da manutenção da ingestão de água. Quando a distensão abdominal era extrema, o fluxo urinário foi preservado, entretanto verificou-se, alternadamente, gotejamento continuo ou em fluxo fraco. À auscultação/sucção dos flancos, notou-se interface líquida e ausência de movimentos ruminais. A punção do abdômen, realizada no flanco direito entre a linha branca e a prega do godinho, deixou fluir abundante quantidade de líquido (Fig. 3) de odor ligeiramente amoniacal e amarelo cítrino. Exames laboratoriais, realizados cerca de duas semanas após o início da evolução, demonstraram, no soro sanguíneo, taxas de ureia e de creatinina entre 220 e $280 \mathrm{mg} / \mathrm{dL}$ e entre 65 e 82mg/dL, respectivamente. Exames do líquido peritoneal revelaram taxas de ureia superiores a 200mg/dL. Verificaram-se hematócrito e contagens de hemácias elevados, sugestivos de hemoconcentração.

Quatro touros foram submetidos à laparotomia exploratória, e outro foi abatido e necropsiado. Para os procedimentos cirúrgicos, os animais foram contidos em tronco em posição quadrupedal. Realizou-se tricotomia na região do flanco esquerdo, no quadrante compreendido entre as apófises transversas das vértebras lombares, $13^{\underline{a}}$ costela, tuberosidade do íleo e região ventral do músculo transverso abdominal. Após assepsia e antissepsia com álcool iodado a $5 \%$, procedeu-se à anestesia local infiltrativa do flanco esquerdo em "L" invertido, com solução de lidocaína 2\%, utilizando-se agulha tipo raquidiana $150 \times 10 \mathrm{~mm}$. O anestésico foi introduzido no tecido celular subcutâneo, músculo oblíquo abdominal externo, músculo oblíquo abdominal interno, músculo reto abdominal na sua porção dorsal e tecido retroperitonial. Uma incisão magistral foi realizada na pele com auxílio de bisturi número 4, incisão magistral dos músculos oblíquo abdominal externo e interno, músculo reto abdominal na sua porção dorsal e peritônio, sendo que as incisões foram de aproximadamente $20 \mathrm{~cm}$, distando $4 \mathrm{~cm}$ das apófises transversas das vértebras lombares e de 3 a $4 \mathrm{~cm}$ da $13^{\mathrm{a}}$ costela. Após drenagem do conteúdo líquido da cavidade abdominal, fez-se identificação dos divertículos da bexiga. Em dois touros, foi possível identificar pequeno orifício distando 4 a $5 \mathrm{~cm}$ do vértex da bexiga, onde fluía urina. Em quatro touros, procedeu-se à ligadura dos divertículos do úraco, próximos ao vértex da bexiga (Fig. 4), 
utilizando-se fio de algodão 000. Em seguida, procedeu-se ao fechamento da cavidade abdominal realizando-se sutura com categute cromado 3 em pontos em $\mathrm{X}$ do peritônio e dos músculos descritos em um único plano. Fez-se sutura do tecido subcutâneo com pontos tipo Shimiden, com categute cromado $\mathrm{n}^{\circ} 2$. A pele foi suturada com fio de náilon $\mathrm{n}^{\circ} 2$ em pontos simples separados. No pós-operatório, empregou-se diariamente a associação de penicilinas $\mathrm{G}$ na dose de $30.000 \mathrm{UI} / \mathrm{kg}$ de peso corporal, além de curativos da ferida cirúrgica com iodopovidona $1 \%$. Os pontos da pele foram retirados no $10^{\circ}$ dia do pós-operatório.

\section{DISCUSSÃO}

Identificou-se a presença de divertículos do úraco, com extravasamento da urina causando uroperitônio. Não houve uma causa aparente para que ocorresse a ruptura ou perfuração dos divertículos. Sabe-se que, nestes animais, o fechamento do úraco era parcial e ocorreu formação de divertículos. Em função da idade e do grande porte dos animais (pesos entre 600 e $1250 \mathrm{~kg}$ ), os divertículos em forma de funil (Fig. 5), com pelo menos $60 \mathrm{~cm}$ de comprimento, localizados entre o vértex da bexiga e o umbigo, propiciaram o acúmulo de urina em uma coluna relativamente extensa, em posição quase que vertical. Ainda, há indícios de que o esvaziamento dos divertículos não ocorria totalmente durante a micção, e de que a urina residual exercia pressão contínua no lúmen do úraco patente, particularmente mais acentuada na extremidade distal ao vértex da bexiga, levando à distensão das paredes, tornando-as delgadas e frágeis. Possivelmente, movimentos bruscos, tais como montas, colheitas de sêmen, ou o aumento da prensa abdominal de origem alimentar, seriam os fatores predisponentes para que ocorressem as rupturas, permitindo o extravasamento da urina para o peritônio, embora, em dois touros, durante a laparotomia exploratória, não tenha sido possível identificar os pontos de ruptura e/ou perfuração.

A distensão abdominal lenta e progressiva, em média de duas semanas, permite inferir que os orifícios de extravasamento da urina eram de pequeno calibre. Em dois touros, um Nelore e outro Gir, evidenciou-se, por meio da laparotomia exploratória, que as perfurações estavam localizadas cerca de $5 \mathrm{~cm}$ no vértex da bexiga. Jubb e Kennedy (1970) afirmaram que as contrações da bexiga tendem a distender o divertículo, porém não ocorrem rupturas.

Relativamente ao volume de urina contido na cavidade peritoneal, foi difícil aquilatar a extensão da retenção. Um touro Nelore, quando admitido, pesava $846 \mathrm{~kg}$ e, após laparotomina exploratória e drenagem da urina através da ferida cirúrgica (Fig. 6) e também com auxílio de sifão (Fig. 7) e após o procedimento cirúrgico, pesava 605kg. Assim, pode-se estimar que, nos touros estudados, o volume de urina acumulada na cavidade peritonial, em um período de aproximadamente duas semanas de evolução, foi superior a $240 \mathrm{~kg}$.

Os quatro touros submetidos à ligadura dos divertículos próxima ao vértex da bexiga apresentaram sintomas de desconforto abdominal (cólica) por pelo menos três dias após o procedimento cirúrgico (Fig. 8), a despeito da cura.

Ruptura de bexiga em touros é um achado relativamente frequente e está correlacionado com obstrução total da uretra por cálculos. Entretanto, pouco se sabe acerca da ruptura do divertículo do úraco causando uroperitônio em touros. Possivelmente, este é um relato pioneiro, não se encontrando na literatura consultada dados semelhantes, o que dificulta uma discussão mais acurada. Aparentemente, a dilatação cística do úraco é assintomática até que ocorra uroperitônio, que causa distensão sequencial nas porções ventral, média e alta do abdômen, em função do acúmulo de urina, e, ainda, devido à uremia que se estabelece gradativamente pelo menos em duas semanas de evolução.

Conclui-se que o diagnóstico de divertículo do úraco em touros requer laparotomia exploratória, e que nem sempre é possível identificar o ponto de perfuração ou ruptura durante o procedimento. O tratamento cirúrgico preconizado mostrou-se eficaz. 

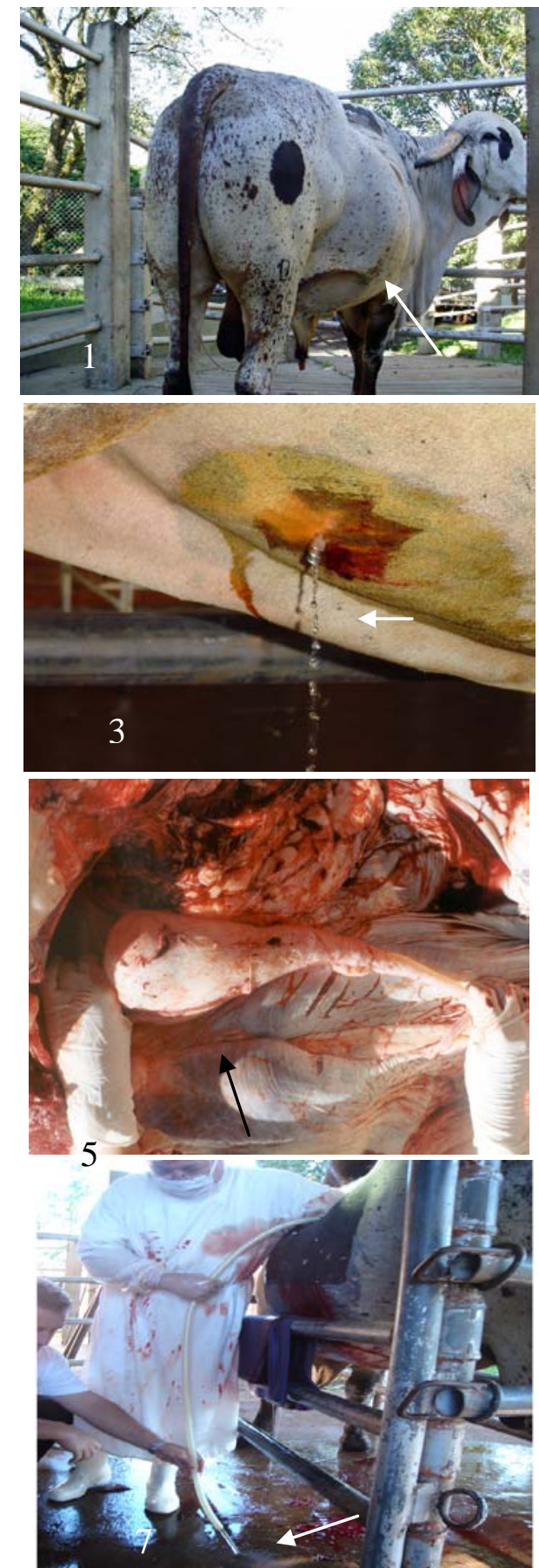
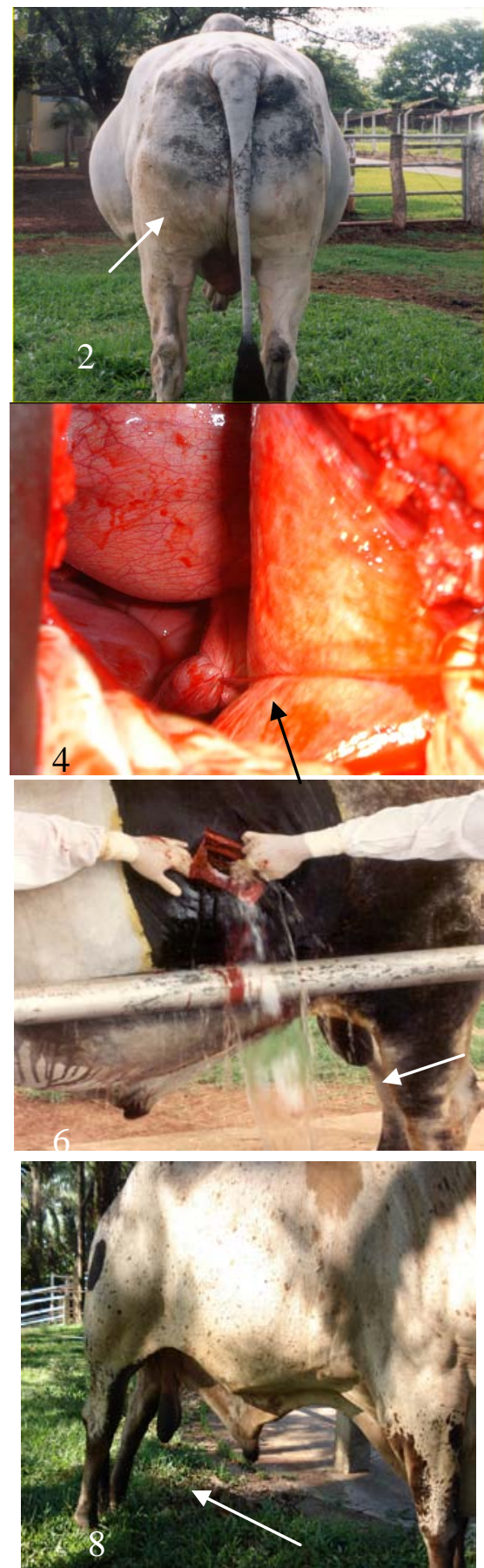

Figuras 1 e 2. Touros com divertículos do úraco perfurados. Notar distensão abdominal exagerada e abdômen com aspecto pendulado. 3. Punção do abdômen. Notar saída de abundante quantidade de fluido. 4. Observar (seta) ligadura realizada em divertículo do úraco próximo ao vértex da bexiga. 5. Divertículo do úraco identificado durante necropsia em touro da raça Red Angus. 6. Notar abundante quantidade de urina fluindo durante laparotomia exploratória. 7. Sifonagem da urina da cavidade peritoneal durante laparotomia. 8. Animal demonstrando desconforto abdominal após o procedimento cirúrgico. Notar membros pélvicos distendidos para trás. 


\section{REFERÊNCIAS BIBLIOGRÁFICAS}

BAXTER, G.M.; ZAMOS, D.T.; MUELLER, P.O. Uroperitoneum attributable to ruptured urachus in a yearling bull. J. Am. Vet. Med. Assoc., v.200, p.517-520, 1992.

BRAUN, U.; NUSS, K.; WAPF, P. et al. Clinical and ultrasonographic findings in five cows with a ruptured urachal remnant. Vet. Rec., v.159, p.780-782, 2006.
JUBB, K.V.F.; KENNEDY, P.C. (Eds). Pathology of domestic animals. 2.ed. New York: Academic, 1970.

NODEN, P.N.; De LAHUNTA, A. Derivatives of the intermediate mesoderm: urinary system, adrenal gland. In: NODEN, P.N.; De LAHUNTA, A. (Eds). Embryiology of domestic animals: developmental mechanisms and malformations. Baltimore:Williams and Wilkins, 1985. p.312-321. 